\title{
Bacteriorhodopsin-ZnO hybrid as a potential sensing element for low-temperature detection of ethanol vapour
}

\author{
Saurav Kumar ${ }^{1,2}$, Sudeshna Bagchi ${ }^{1,2}$, Senthil Prasad ${ }^{3}$, Anupma Sharma $^{1,2}$, \\ Ritesh Kumar ${ }^{1,2}$, Rishemjit Kaur ${ }^{1,2}$, Jagvir Singh ${ }^{4}$ and Amol P. Bhondekar ${ }^{* 1,2}$
}

\author{
Full Research Paper \\ Address: \\ ${ }^{1}$ CSIR-Central Scientific Instruments Organisation, Sector 30C, \\ Chandigarh 160030, India, ${ }^{2}$ Academy of Scientific and Innovative \\ Research, Rafi Marg, New Delhi 110011, India, ${ }^{3}$ CSIR- Institute of \\ Microbial Technology, Sector 39A, Chandigarh 160036, India, and \\ ${ }^{4}$ Research Services, University of Alberta, Edmonton, AB, Canada \\ T6G2E1 \\ Email: \\ Amol P. Bhondekar* - amol.bhondekar@gmail.com \\ * Corresponding author \\ Keywords: \\ amphipol; bacteriorhodopsin; bio-hybrid; gas sensing; ITO; ZnO \\ nanostructure \\ Beilstein J. Nanotechnol. 2016, 7, 501-510. \\ doi:10.3762/bjnano.7.44 \\ Received: 28 August 2015 \\ Accepted: 22 March 2016 \\ Published: 04 April 2016 \\ Associate Editor: N. Motta \\ (c) 2016 Kumar et al; licensee Beilstein-Institut. \\ License and terms: see end of document.
}

\begin{abstract}
Zinc oxide $(\mathrm{ZnO})$ and bacteriorhodopsin $(\mathrm{bR})$ hybrid nanostructures were fabricated by immobilizing bR on $\mathrm{ZnO}$ thin films and $\mathrm{ZnO}$ nanorods. The morphological and spectroscopic analysis of the hybrid structures confirmed the $\mathrm{ZnO}$ thin film/nanorod growth and functional properties of $b R$. The photoactivity results of the $b R$ protein further corroborated the sustainability of its charge transport property and biological activity. When exposed to ethanol vapour (reducing gas) at low temperature $\left(70{ }^{\circ} \mathrm{C}\right)$, the fabricated sensing elements showed a significant increase in resistivity, as opposed to the conventional n-type behaviour of bare $\mathrm{ZnO}$ nanostructures. This work opens up avenues towards the fabrication of low temperature, photoactivated, nanomaterial-biomolecule hybrid gas sensors.
\end{abstract}

\section{Introduction}

Nanomaterial-biomolecule conjugates have emerged into one of the most rapidly developing and sought after areas in modern biomolecular device fabrication and sensor design [1-4]. Novel approaches towards sensor design that employ biological material as the active element or associated active element have been widely explored $[5,6]$. Over the last few decades, the research in this domain has been directed towards the bio-inspired, selfassembly of monolayer/multilayer of thin films, biosensors, and protein-based photonic devices [7-9].

The application of proteins for enhancement in signal transduction has been demonstrated by a number of researchers $[1,10]$. 
In general, the major drawbacks associated with proteins are their low stability, poor retention of functional properties ex vivo, and a lack of immobilization techniques to prevent denaturation $[4,8]$. Interestingly, the protein bacteriorhodopsin (bR) has been proven to have significant stability against thermal, chemical and photochemical degradation [11-13]. Also, bR maintains its biological activity after immobilization on solid supports and exhibits charge transport in thin films $[8,14,15]$. These properties have attracted researchers for the development of novel bio-hybrid devices [5,7,16-19]. Hybrids of bR protein with various metal/metal oxides (e.g., $\mathrm{Au}, \mathrm{Ag}, \mathrm{TiO}_{2}, \mathrm{SiO}_{2}$ ) and polymers (e.g., PVA, gelatine) have been explored for photo-energy conversion, energy storage devices and gas sensing based on photo-conductive activity [12,14,20-22].

In parallel, $\mathrm{ZnO}$ and its hybrids have evolved as promising structures for sensing and semiconductor applications [23,24]. The preference of $\mathrm{ZnO}$ in applications for the formation of hybrid structures is due to its high band gap (3.39 eV), large excitonic binding energy $(60 \mathrm{meV})$, and high isoelectric point (9.2) [23,25-27]. One of the early reported works by Heiland in 1959 demonstrated the use of $\mathrm{ZnO}$ as a gas sensing material [28]. Further, the advancement in concepts and techniques in nanotechnology resulted in the demonstration of the gas sensing capabilities of $\mathrm{ZnO}$-based nanostructures [29,30].

Recently, researchers have explored innovative hybrid nanostructures based on the interaction of organic and inorganic materials in order to overcome the intrinsic limitations of $\mathrm{ZnO}$ (i.e., poor selectivity and high working temperature) [31-33]. Metal/metal oxide-bR hybrids were previously reported for biooptoelectronic and solar cell applications [7,20]. However, a hybrid structure employing $\mathrm{ZnO}$ and $\mathrm{bR}$ protein has not been explored yet for gas sensing applications to the best of our knowledge. This work explores the possibility of overcoming the intrinsic limitations of $\mathrm{ZnO}$, in particular the high operating temperature, by creating a $\mathrm{ZnO} / \mathrm{bR}$ hybrid structure that exploits the charge transfer mechanism of $b R$.

\section{Results}

In this work, $\mathrm{ZnO}$ thin films ( $\mathrm{ZnO}-\mathrm{TF})$ and $\mathrm{ZnO}$ nanorods ( $\mathrm{ZnO}-\mathrm{NRs})$ were grown via the hydrothermal method on indium tin oxide (ITO) substrates $(25 \times 25 \mathrm{~mm})$ and both structures were used for the preparation of a sensitive film for gas testing. The precursor solution (zinc acetate dihydrate in 2-propanol reduced with monoethanolamine) was prepared using the sol-gel method and was spin-coated, layer-by-layer, to form the $\mathrm{ZnO}-\mathrm{TF}$. Further, the $\mathrm{ZnO}-\mathrm{TF}$ was annealed $\left(400^{\circ} \mathrm{C}\right)$ for an hour in order to obtain a uniform size distribution of the $\mathrm{ZnO}$ grains [34]. The resulting average thickness and resistance of this film were observed to be $275 \pm 10 \mathrm{~nm}$ and $2.22 \times 10^{2} \Omega$, re- spectively. The film was further utilized for two purposes: to form $\mathrm{ZnO}-\mathrm{TF} / \mathrm{bR}$ and $\mathrm{ZnO}-\mathrm{TF} / \mathrm{ZnO}-\mathrm{NR} / \mathrm{bR}$ hybrid nanostructures. The synthesis of $\mathrm{ZnO}-\mathrm{NRs}$ was carried out by suspending the seed layer $(\mathrm{ZnO}-\mathrm{TF})$ upside down in the growth solution consisting of zinc nitrate and hexamine. This inverted growth scheme was preferred in order to avoid contamination effects due to sedimentation and to achieve a uniform growth pattern $[35,36]$. Further, the suspension of wild-type, photoactive bR was prepared with aqueous amphipol (A8-35) in a 1:5 ratio in order to retain the conformational stability of $b R$ in the solution phase without affecting its photoactive properties [37]. The drop casting method was used for the deposition of this suspension on the $\mathrm{ZnO}-\mathrm{TF}$ as well as $\mathrm{ZnO}-\mathrm{NRs}$ [14]. This modification serves to enhance the surface activity, which in turn enables the charge transfer in $\mathrm{ZnO}-\mathrm{TF} / \mathrm{bR}$ and $\mathrm{ZnO}-\mathrm{NR} / \mathrm{bR}$ interfaces [10,14].

In order to characterize the morphological changes, the surface of the hybrid structures was investigated by X-ray diffraction (XRD) and scanning electron microscopy (SEM). Figure 1 shows the XRD patterns of the ZnO-TF and ZnO-NRs on an ITO substrate, confirming the presence of $\mathrm{ZnO}$. The strong peaks are in good agreement with the characteristic peaks of $\mathrm{ZnO}$ (marked with asterisk). A sharp peak at $34.4^{\circ}$ indicates the preferential growth of the $\mathrm{ZnO}-\mathrm{NRs}$ along the $c$-axis, normal to the substrate corresponding to the lattice plane (002) (JCPDS card number 36-1451) [38,39]. The average $\mathrm{ZnO}$ crystallite size on the $\mathrm{ZnO}-\mathrm{TF}$ (as calculated by Scherrer's equation) is $30 \mathrm{~nm}$ [40]. Further, the presence of bR on both the structures (synthesized under similar conditions) is supported by the significant difference in the intensity values of the XRD peaks with and without bR protein.

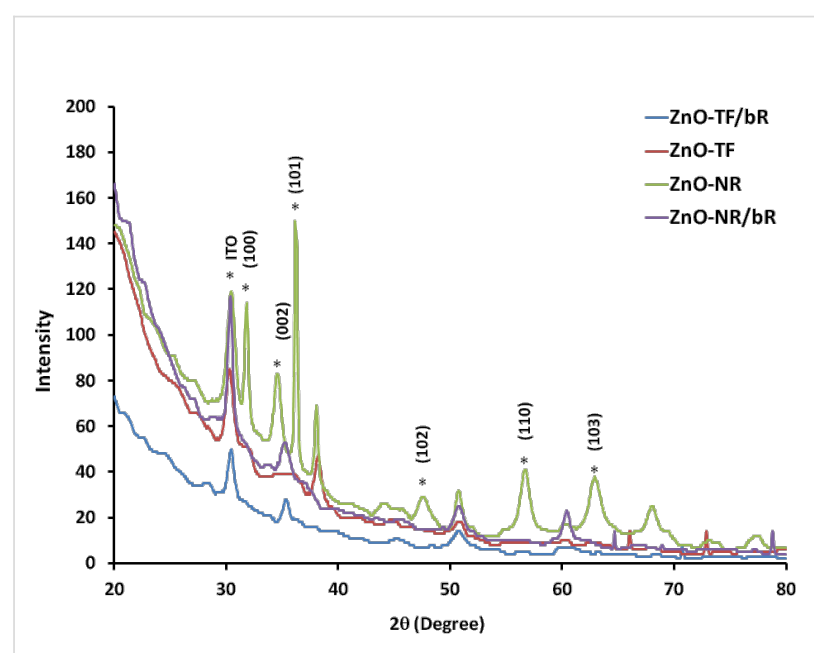

Figure 1: Comparative XRD patterns of the $\mathrm{ZnO}-\mathrm{TF}, \mathrm{ZnO}-\mathrm{TF} / \mathrm{bR}$, $\mathrm{ZnO}-\mathrm{NR}$ and $\mathrm{ZnO}-\mathrm{NR} / \mathrm{bR}$ structures. 
Figure 2a-d shows SEM images of ZnO-TF, ZnO-NR on an ITO substrate and their respective hybrid structures with $b R$. The diameter of the hexagonal $\mathrm{ZnO}$ particles was found to be between $90-110 \mathrm{~nm}$ (average size $70 \mathrm{~nm}$ ) in the Figure 2a. It can be observed from Figure $2 b$ that the NRs are uniformly distributed and likely perpendicular to the substrate surface. The image shows the vertical growth of the rods with length $900-1300 \mathrm{~nm}$ and diameter $90-110 \mathrm{~nm}$. The morphology of the hybrid structures ( $\mathrm{ZnO}-\mathrm{TF} / \mathrm{bR}$ and $\mathrm{ZnO}-\mathrm{NR} / \mathrm{bR})$ was distinctly different from nonhybrid structures, as is evident from Figure 2c,d.

The structural and optical properties of $\mathrm{ZnO}-\mathrm{TF}, \mathrm{ZnO}-\mathrm{NR}$ and their hybrid structures were assessed using UV-vis spectroscopy, photoluminescence spectroscopy (PL), Raman spectroscopy and Fourier transform infrared spectroscopy (FTIR). Figure 3 shows the absorbance spectra of $\mathrm{ZnO}-\mathrm{TF}, \mathrm{ZnO}-\mathrm{NR}$, bR solution in amphipol (bR/A8-35, inset figure) and the hybrid nanostructures. The UV-vis spectra of $\mathrm{ZnO}-\mathrm{TF}$ and $\mathrm{ZnO}-\mathrm{NR}$ show absorption near the band edge in the exciton absorption region at $372 \mathrm{~nm}$ and $347 \mathrm{~nm}$, respectively [41]. These band edge absorptions have a similar trend in the respective hybrid structures, $362 \mathrm{~nm}$ for $\mathrm{ZnO}-\mathrm{TF} / \mathrm{bR}$ and $358 \mathrm{~nm}$ for $\mathrm{ZnO}-\mathrm{NR} / \mathrm{bR}$. The blue shift in the excitonic absorption may be due to the reduction of grain size and improved structural quality of the surface. It is an indication of the increase in the band gap energy as the result of crystallization and strain factor $[42,43]$. The hybrid structures, $\mathrm{ZnO}-\mathrm{TF} / \mathrm{bR}$ and $\mathrm{ZnO}-\mathrm{NR} / \mathrm{bR}$, show two specific characteristic peaks at $270 \mathrm{~nm}$ and $570 \mathrm{~nm}$ (inset

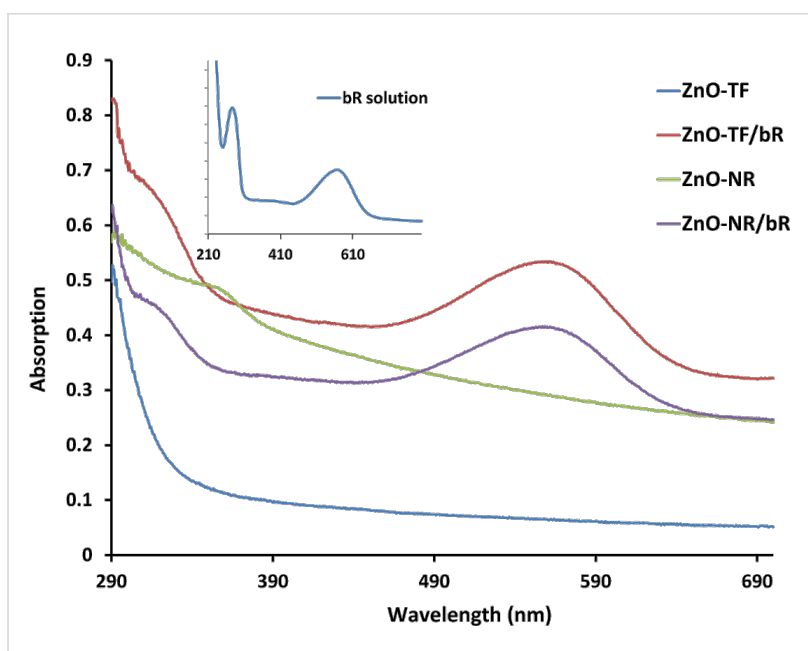

Figure 3: UV-vis spectra of ZnO-TF (blue); ZnO-NR/bR (purple); $\mathrm{ZnO}-\mathrm{NR}$ (green) and $\mathrm{ZnO}-\mathrm{TF} / \mathrm{bR}$ (red) structures. The absorption spectrum of the $b R$ protein (inset) indicates two specific absorption peaks of photoactive bR protein at $570 \mathrm{~nm}$ and $270 \mathrm{~nm}$ (in a 1 to $2 \mathrm{in}$ tensity ratio).

figure), respectively. These are due to the superposition of the bands attributed to the aromatic residue of bR (including 8-tryptophan and 11- tyrosine) [44] and the $\pi-\pi^{*}$ transition in the retinal chromophore between two different energy levels upon exposure to the light $[45,46]$. However, the characteristic absorbance of bR due to retinal absorption at $570 \mathrm{~nm}$ was blueshifted by $5 \mathrm{~nm}$ in $\mathrm{ZnO}-\mathrm{TF} / \mathrm{bR}$ and $\mathrm{ZnO}-\mathrm{NR} / \mathrm{bR}$ hybrids, which may be due to the interaction between the permanent dipole of retinal and charge layer of $\mathrm{ZnO}[46,47]$.
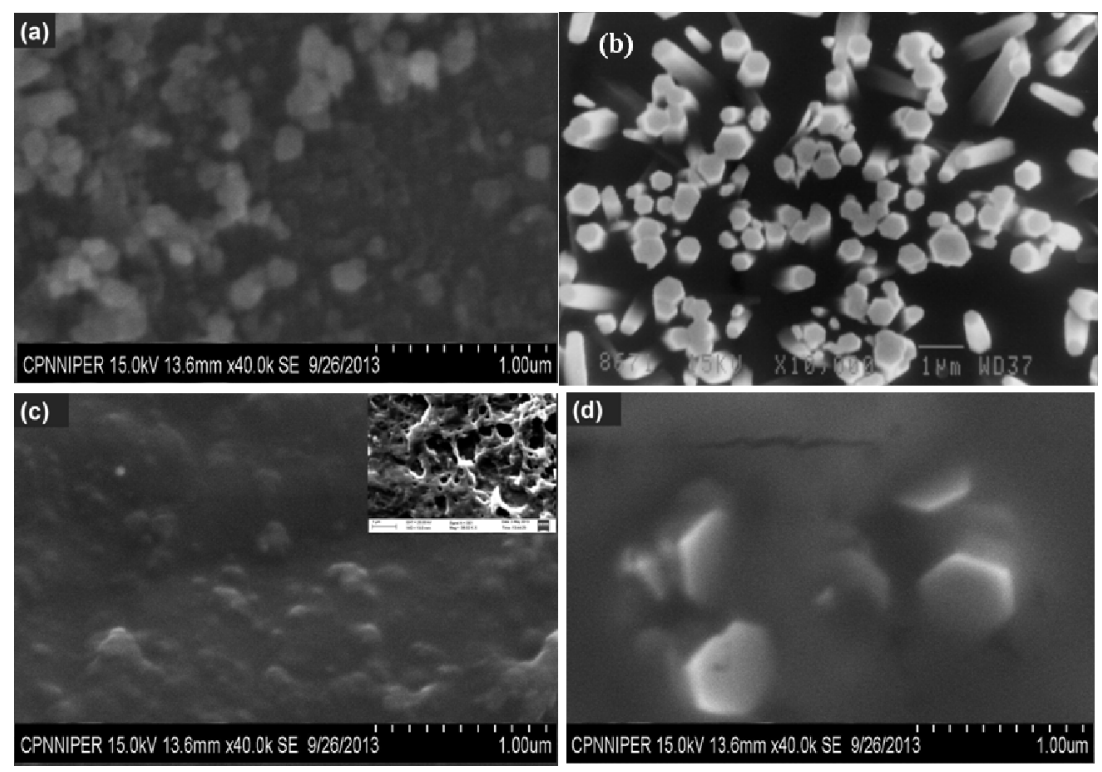

Figure 2: SEM characterization. (a) ZnO-TF has grown over the ITO substrate and was annealed at $400{ }^{\circ} \mathrm{C}$. (b) $\mathrm{ZnO}-\mathrm{NR}$ structure grown over the $\mathrm{ZnO}-\mathrm{TF}$ seed layer. (c) ZnO-TF/bR hybrid structure prepared by drop casting. (d) ZnO-NR/bR hybrid structure. 
Figure 4 illustrates the PL spectrum of $\mathrm{ZnO}-\mathrm{TF}$ and $\mathrm{ZnO}-\mathrm{NR}$ (at an excitation wavelength of $320 \mathrm{~nm}$ ) and their hybrid structures (at an excitation wavelength of $320 \mathrm{~nm}$ and $280 \mathrm{~nm}$ ). The strong emission band close to $368 \mathrm{~nm}$ is the band edge emission, and the emission around $383 \mathrm{~nm}$ may be attributed to the recombination of free excitons through an exciton-exciton collision process $[48,49]$. Also, the peak positions were almost same in $\mathrm{ZnO}-\mathrm{TF}$ and $\mathrm{ZnO}-\mathrm{TF} / \mathrm{bR}$, whereas a red shift of $6 \mathrm{~nm}$ was observed in $\mathrm{ZnO}-\mathrm{NR}$ and $\mathrm{ZnO}-\mathrm{NR} / \mathrm{bR}$. This red shift may be due to the microcavity effect of $\mathrm{ZnO}-\mathrm{NRs}$ and its excitonic recombination with the emission of bR protein [50]. Visible band emissions were not prominent in any of the structures, suggesting the absence of structural defects and impurities [51,52], as well as higher crystallization and less oxygen vacancies [53]. As observed from Figure 4, the PL intensity increases with increasing excitation wavelength (i.e., $280 \mathrm{~nm}$ and $320 \mathrm{~nm}$ ), which may be attributed to electron-hole plasma recombination shift by band renormalization [54].

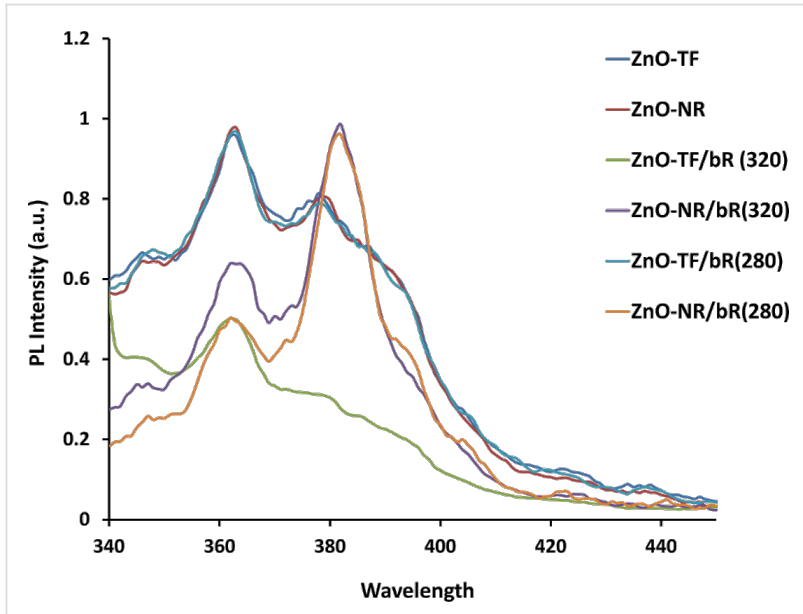

Figure 4: Photoluminescence spectral analysis for the ITO/ZnO-TF and ITO/ZnO-NR structures, and the respective hybrid structure for the structural analysis of the surface.

Figure 5 shows the Raman spectra for all the structures at $514 \mathrm{~nm}$ excitation wavelength. $\mathrm{ZnO}$ has wurtzite symmetry with the $\mathrm{C}_{6 v}$ point group. Group theory predicts that there is an $A_{1}$ branch, a doubly degenerate $E_{1}$ branch, two doubly degenerate $E_{2}$ branches, and two $B$ branches. The $A_{1}, E_{1}$ and $E_{2}$ modes are Raman active; the $\mathrm{B}$ modes are inactive [55]. It can be observed from Figure 5a that the fundamental optical mode vibrations are at $437 \mathrm{~cm}^{-1}$ and $583 \mathrm{~cm}^{-1}$ corresponding to the $\mathrm{E}_{2}$ mode and $\mathrm{A}_{1}(\mathrm{LO})$ mode, respectively, in $\mathrm{ZnO}-\mathrm{TF}[56,57]$ The $\mathrm{E}_{2}$ mode is associated with the vibration of the heavy $\mathrm{Zn}$ sublattice of crystalline wurzite $\mathrm{ZnO}$, and the $\mathrm{A}_{1}(\mathrm{LO})$ mode is associated with intrinsic lattice defects $[58,59]$. The Raman spectra of $\mathrm{ZnO}-\mathrm{NR}$ in Figure $5 \mathrm{c}$ shows a shift in the $\mathrm{A}_{1}(\mathrm{LO})$ mode vibration by $8 \mathrm{~cm}^{-1}$, indicating the possibility of a confinement effect [60]. The vibrational spectra of the hybrid structures (Figure 5b,d) shows characteristic peaks of bR protein at $1528 \mathrm{~cm}^{-1}(\mathrm{C}=\mathrm{C}$ stretching $)$ and fairly strong fingerprint spectra in the range of $1150-1220 \mathrm{~cm}^{-1}$ (C-C stretching) [61]. However, there is a small shift in the characteristic vibrational modes of $b R$, which may be due to the electrostatic interaction between the $\mathrm{ZnO}$ and bR protein [62].

Figure 6 shows the FTIR spectra for the $\mathrm{ZnO}-\mathrm{TF}$ and $\mathrm{ZnO}-\mathrm{NR}$ structures, and their respective hybrid structures $(\mathrm{ZnO}-\mathrm{TF} / \mathrm{bR}$ and $\mathrm{ZnO}-\mathrm{NR} / \mathrm{bR}$ ). Spectral analysis of the hybrid structures shows a shift in the frequency of the characteristic peaks of bR protein [63-67], which might be due to the electrostatic interaction between the $\mathrm{bR}$ protein and the $\mathrm{ZnO}$ nanostructures $[68,69]$. The peak at $1040 \mathrm{~cm}^{-1}$ (region $880-1050 \mathrm{~cm}^{-1}$ ) shows the hydrogen out-of-plane (HOOP) vibrational mode, which indicates a twist in the skeleton of the protein. The comparatively weak feature within $1150-1500 \mathrm{~cm}^{-1}$ may be attributed to $\mathrm{C}-\mathrm{O}-\mathrm{C}$ asymmetric stretching, $\mathrm{O}-\mathrm{H}$ bending, $\mathrm{C}=\mathrm{C}$ stretching and $\mathrm{C}-\mathrm{H}$ bending of the retinal chromophore, amino acids and lipids [66]. Further investigation indicates a small change in the amide I vibration spectra (at $1660 \mathrm{~cm}^{-1}$ ) due to the $\mathrm{C}=\mathrm{O}$ stretch in the skeleton and amide II vibration spectra (at $1540 \mathrm{~cm}^{-1}$ ) due to $\mathrm{N}-\mathrm{H}$ in-plane bending, which reflects the secondary structure of the protein ( $\beta$-structure) [70-72]. Higher frequencies at $3070,2950,2920$ and $2850 \mathrm{~cm}^{-1}$ are attributed to the alkyl $\mathrm{C}-\mathrm{H}$ stretching vibration of both lipid and protein amino acid $[63,65,73]$.

The gas sensing tests were carried at 55,65 and $70{ }^{\circ} \mathrm{C}$ for 50 , 100 and $200 \mathrm{ppm}$ concentrations of ethanol gas under ambient light conditions using a standard Taguchi gas sensing kit [74]. It has been widely reported that bR denatures between 75 to $100{ }^{\circ} \mathrm{C}$, depending upon its phase, morphology, experimental conditions, etc. In order to protect our sample, excessive temperatures were avoided, and the experiments were restricted to $70{ }^{\circ} \mathrm{C}$. A noticeable increase in the resistance of the $\mathrm{ZnO}-\mathrm{TF} / \mathrm{bR}$ and $\mathrm{ZnO}-\mathrm{NR} / \mathrm{bR}$ structures was observed upon exposure to ethanol gas of $50 \mathrm{ppm}, 100 \mathrm{ppm}$, and $200 \mathrm{ppm}$ concentrations. Figure 7a,b shows the response of the $\mathrm{ZnO}-\mathrm{TF} / \mathrm{bR}$ and $\mathrm{ZnO}-\mathrm{NR} / \mathrm{bR}$ structures for the consecutive concentration increase (50 ppm, $100 \mathrm{ppm}, 200 \mathrm{ppm})$ at $70{ }^{\circ} \mathrm{C}$. The response time for the $\mathrm{ZnO}-\mathrm{TF} / \mathrm{bR}$ and $\mathrm{ZnO}-\mathrm{NR} / \mathrm{bR}$ structures was observed to be 11 and $4.3 \mathrm{~min}$, respectively, and the recovery time was 1.7 and $1.5 \mathrm{~min}$, respectively. The experiments were repeated to ensure stability of the response of the hybrid structures, wherein no significant difference was observed. This confirmed that the deposited bR did not denature. Figure $7 \mathrm{c}$ shows the response of the $\mathrm{ZnO}-\mathrm{TF}$ and $\mathrm{ZnO}-\mathrm{TF} / \mathrm{bR}$ structures at $70{ }^{\circ} \mathrm{C}$ for $100 \mathrm{ppm}$ concentration, and Figure $7 \mathrm{~d}$ shows the response of the $\mathrm{ZnO}-\mathrm{NR}$ and $\mathrm{ZnO}-\mathrm{NR} / \mathrm{bR}$ structures at $70{ }^{\circ} \mathrm{C}$ for $100 \mathrm{ppm}$ 

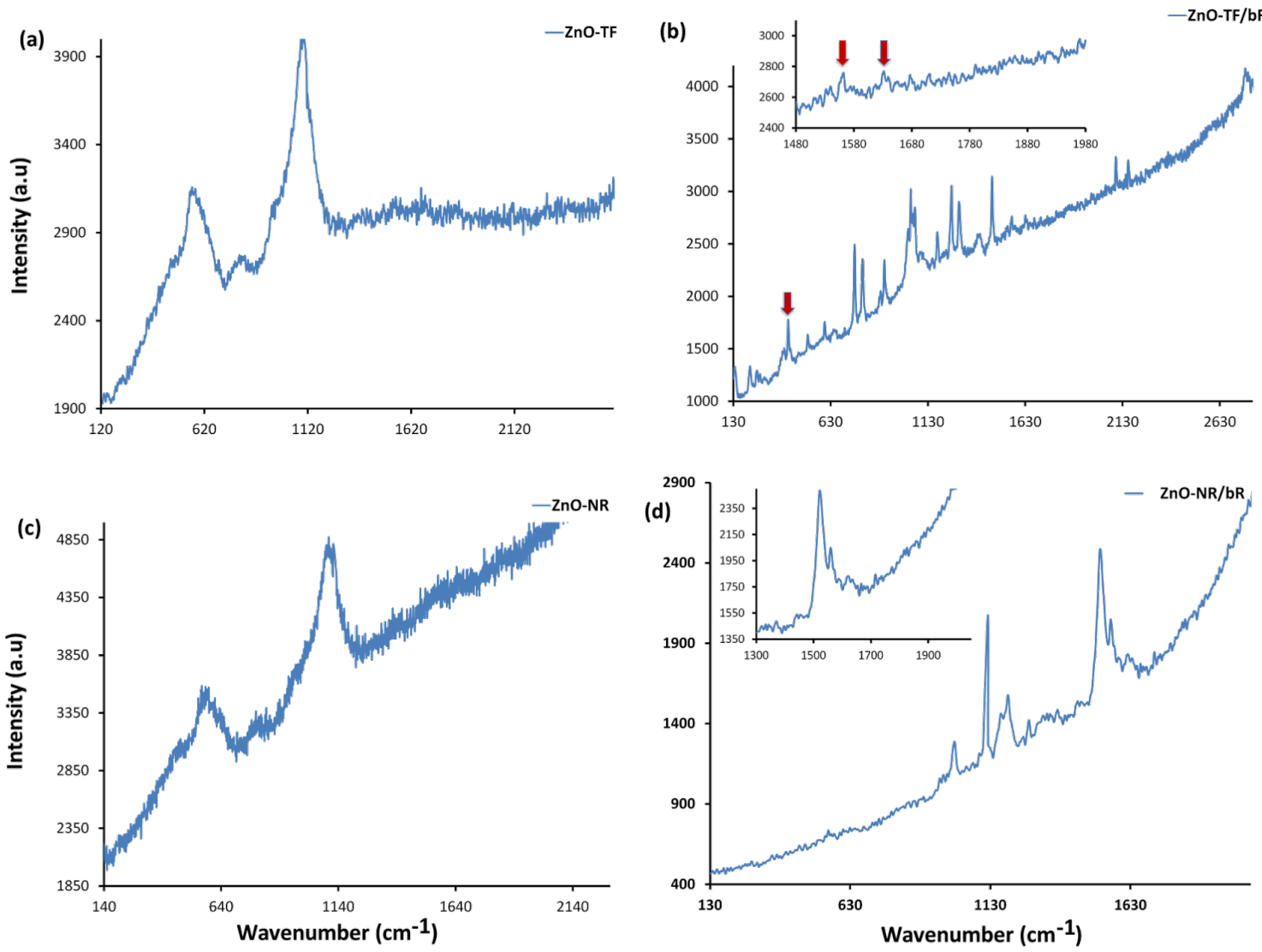

Figure 5: Raman spectra. (a) ZnO-TF shows the characteristic peaks for $\mathrm{ZnO}$ at $467 \mathrm{~cm}^{-1}, 563 \mathrm{~cm}^{-1}$ and $800 \mathrm{~cm}{ }^{-1}$; (b) ZnO-TF/bR hybrid structure showing characteristic peaks of both $\mathrm{ZnO}$ and $\mathrm{bR}$, indicating the preservation of the functional properties of the protein. Inset image shows amide I and amide II peaks of bR protein. (c) ZnO-NR structure illustrates the major ZnO vibrational peaks at $476 \mathrm{~cm}^{-1}, 570 \mathrm{~cm}^{-1}, 806 \mathrm{~cm}^{-1}$ and $1106 \mathrm{~cm}^{-1}$. (d) ZnO-NR/bR hybrid structure. Inset image shows specific amide I and amide II peak of bR protein.

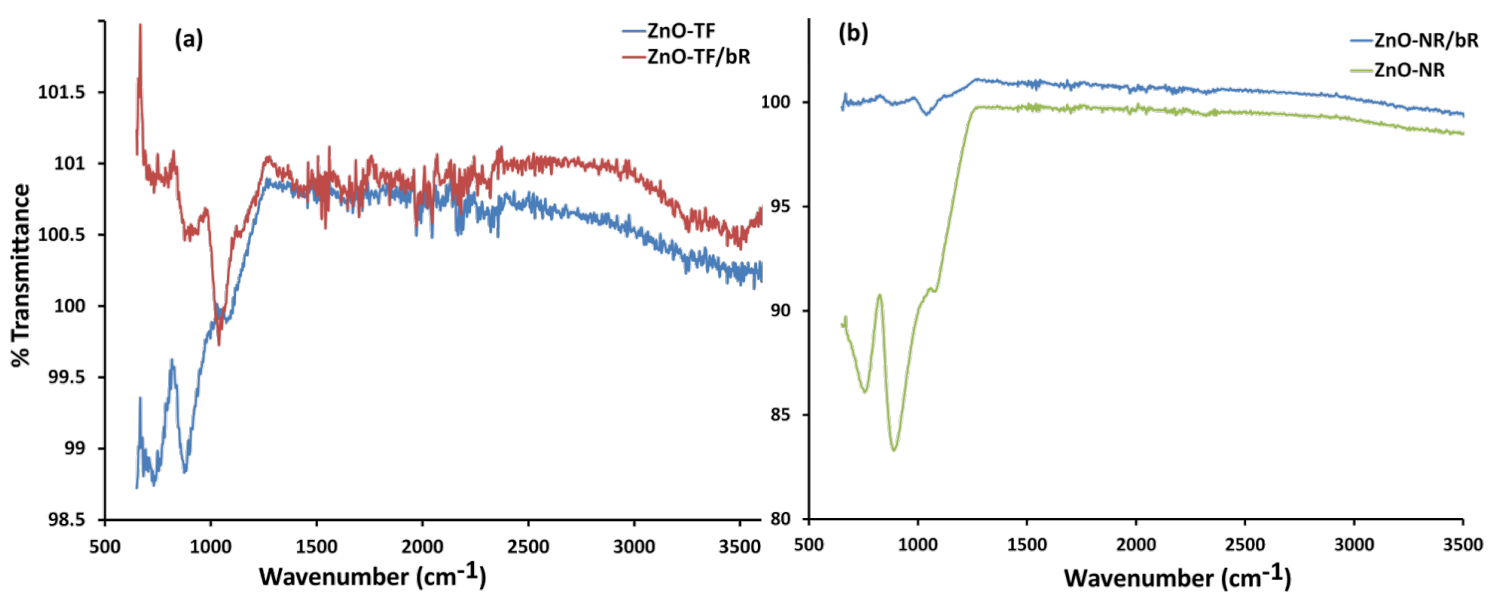

Figure 6: FTIR spectral analysis. (a) ZnO-TF and ZnO-NR/bR; (b) ZnO-NR and ZnO-NR/bR. The vibrational spectra of the ZnO-TF and ZnO-NR structures show the characteristic peaks of $\mathrm{ZnO}$ with a red shift $\left(\approx 10 \mathrm{~cm}^{-1}\right)$ in the $\mathrm{ZnO} / \mathrm{NR}$ structure, indicating the possibility of a confinement effect. The characteristic vibrational modes of bR were also observed in the hybrid structures with a small red shift. 

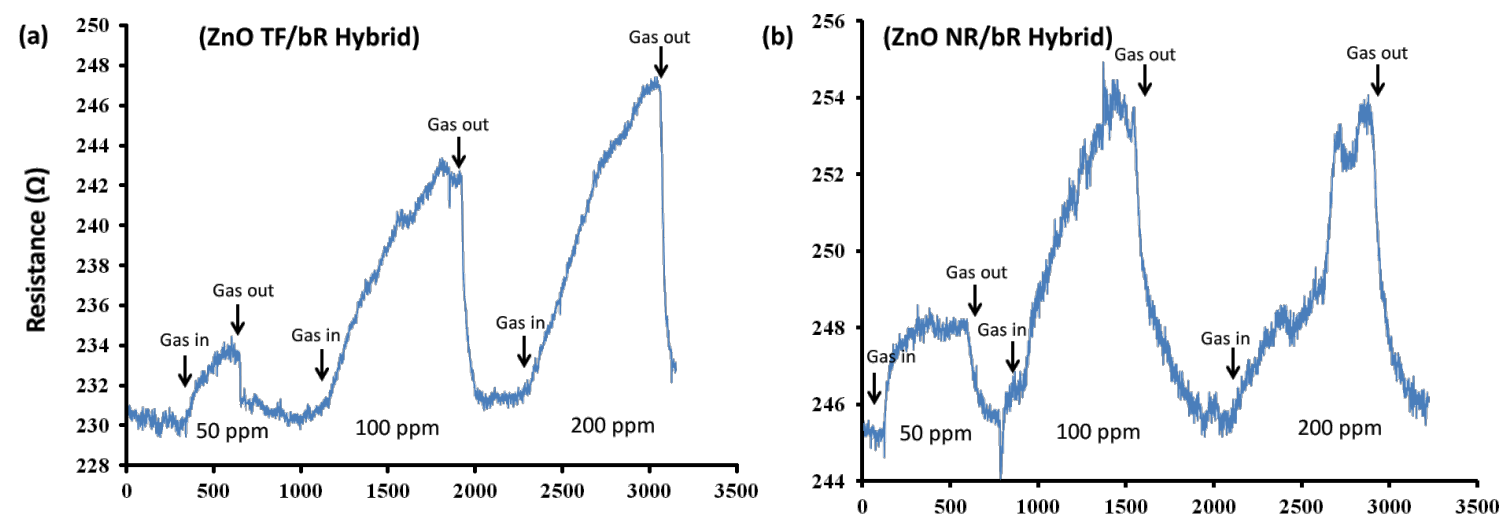

(c)

(d)
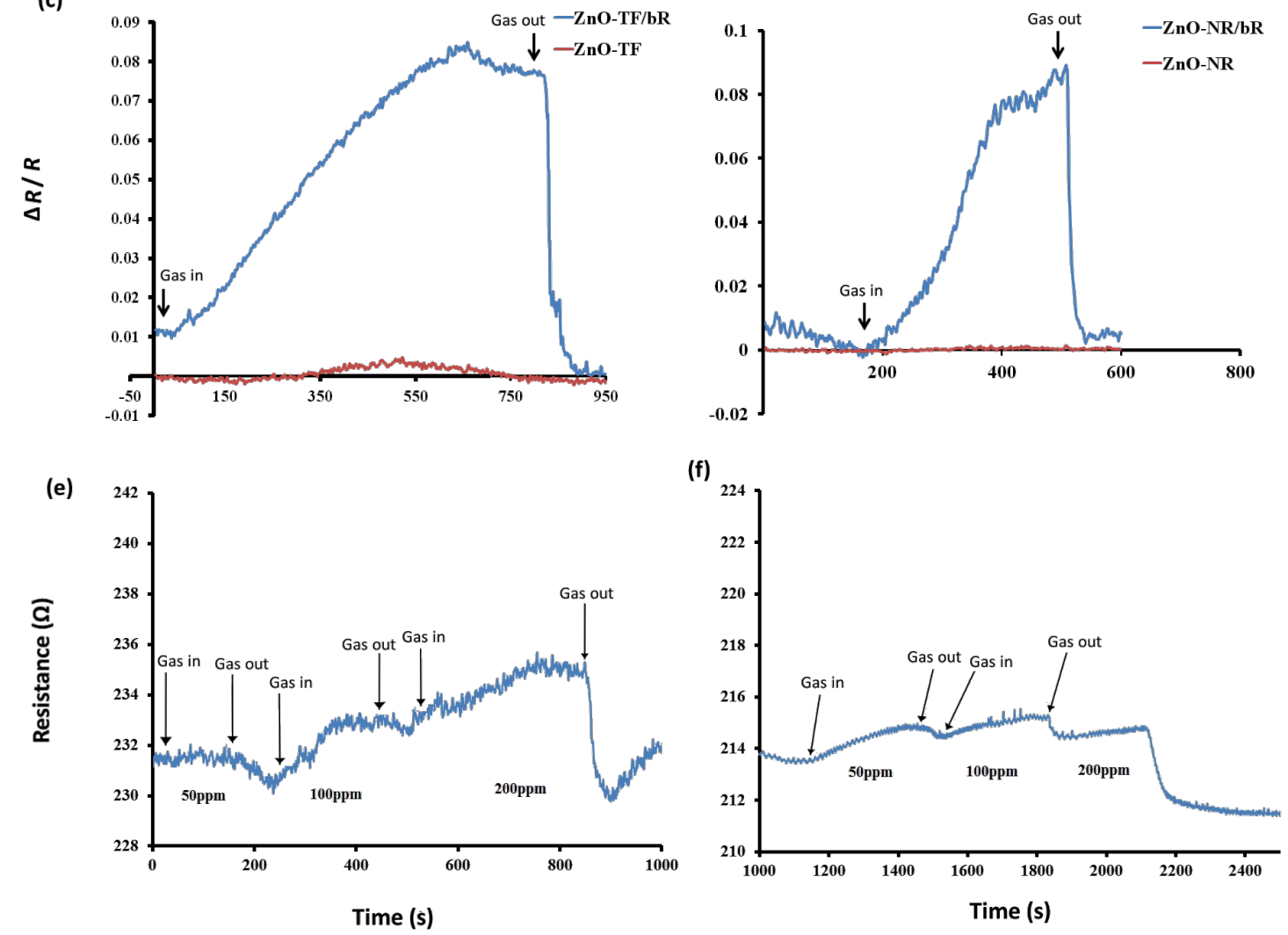

Figure 7: Dynamic response of the ethanol vapour sensing tests at $70{ }^{\circ} \mathrm{C}$ for 50,100 and $200 \mathrm{ppm}$ concentrations for (a) $\mathrm{ZnO}-\mathrm{TF} / \mathrm{bR}$ and (b) ZnO-NR/bR structures. Comparative dynamic response diagram of hybrid and nonhybrid ZnO structures at $70{ }^{\circ} \mathrm{C}$ for $100 \mathrm{ppm}$ concentration for (c) $\mathrm{ZnO}-\mathrm{TF}$ and $\mathrm{ZnO}-\mathrm{TF} / \mathrm{bR}$, and (d) $\mathrm{ZnO}-\mathrm{NR}$ and $\mathrm{ZnO}-\mathrm{NR} / \mathrm{bR}$. A similar response at $65^{\circ} \mathrm{C}$ for the 50,100 and 200 ppm concentrations is shown for (e) $\mathrm{ZnO}-\mathrm{TF} / \mathrm{bR}$ and (f) ZnO-NR/bR.

concentration. In both cases the enhancement in sensitivity of the hybrid structures is noticeable. Figure $7 \mathrm{e}$,f shows the poor response of the hybrid structures at $65^{\circ} \mathrm{C}$.

The n-type gas sensing behaviour of $\mathrm{ZnO}$ at very high temperature $\left(\geq 300{ }^{\circ} \mathrm{C}\right)$ is accompanied by the dehydration/dehydrogenation reaction of ethanol, releasing $\mathrm{CO}_{2}$ and $\mathrm{H}_{2} \mathrm{O}$ [75]. However, contrary to this, both the hybrid structures in our study showed p-type behaviour. This observed inconsistency is due to the increase in barrier height of approximately $2.90 \mathrm{meV}$ for the $\mathrm{ZnO}-\mathrm{NR}$ and $2.10 \mathrm{meV}$ for the $\mathrm{ZnO}-\mathrm{TF}$ hybrid structure (measured from the work function equation), thus contributing to the overall increase in resistance [76]. One of the possible explanations can be the dipole-dipole interactions between the extracellular site of the protein and ethanol molecules, which leads to the electron transfer between the surface and the interior layer [77,78]. Secondly, the direct adsorption of ethanol molecules may cause changes in the morphology of protein 
molecules, resulting in an increase in the surface resistance [77]. The formation of localized heterojunctions at the $\mathrm{ZnO} / \mathrm{bR}$ nanostructure, and the possibility of exchanging charge carriers at the hybrid interface, are expected to strongly affect the electronic properties of the resulting nano-hybrid material. The hybrid $\mathrm{ZnO}-\mathrm{TF} / \mathrm{bR}$ and $\mathrm{ZnO}-\mathrm{NR} / \mathrm{bR}$ structures form the main percolative network through which charge carriers can move $[79,80]$.

\section{Conclusion}

Nanomaterial-biomolecule hybrids based on ZnO-TF or $\mathrm{ZnO}-\mathrm{NR}$ functionalized with bR protein have been successfully fabricated on ITO substrates. The morphological, optical, and electrical characterization of these devices was presented. The behaviour of $\mathrm{ZnO}-\mathrm{TF} / \mathrm{bR}$ and $\mathrm{ZnO}-\mathrm{NR} / \mathrm{bR}$ hybrids has been studied upon exposure to ethanol vapour at 50,100 and $200 \mathrm{ppm}$ concentrations at 55,65 and $70{ }^{\circ} \mathrm{C}$. The sensing results for both the nano-hybrid structures showed good response towards ethanol gas at $70^{\circ} \mathrm{C}$. Typically, $\mathrm{ZnO}$ shows n-type behaviour upon exposure to reducing gases like ethanol, whereas p-type behaviour has been observed in the hybrids. This may be attributed to the heterojuction of $\mathrm{ZnO} / \mathrm{bR}$, which provides a percolative network for the movement of charge carrier. This work demands further investigation related to device characteristics (e.g., specificity, sensitivity, photoactivity, concentration variability, threshold limit) and device fabrication with more precision with application specificity.

\section{Experimental \\ $\mathrm{ZnO}$ thin film (ZnO-TF) preparation}

$\mathrm{ZnO}$ nanoparticles were synthesized by hydrothermal growth $[81,82]$. Zinc acetate dihydrate $(0.1 \mathrm{M})$ was dissolved in $20 \mathrm{~mL}$ of propanol. This solution was stirred at $40-60{ }^{\circ} \mathrm{C}$ for $5-10 \mathrm{~min}$. Then, monoethanolamine $(0.1 \mathrm{M})$ was poured drop-by-drop into the solution. A clear transparent solution so obtained was stirred at $500 \mathrm{rpm}$ for $2 \mathrm{~h}$. This solution was kept in dark for the next $12 \mathrm{~h}$ and used for coating. Spin coating (Millman, single-stage coating unit) was performed at $3000 \mathrm{rpm}$ for $20 \mathrm{~s}$ to obtain a thin film of $\mathrm{ZnO}$ nanoparticles.

\section{$\mathrm{ZnO}$ nanorod (ZnO-NR) synthesis}

$\mathrm{ZnO}-\mathrm{NRs}$ were grown on the $\mathrm{ZnO}-\mathrm{TF}$ substrate by the hydrothermal method $[36,83]$. Zinc nitrate hexahydrate $(0.2 \mathrm{M})$ was used as a precursor salt and was dissolved in aqueous ethanol $(30 \%)$. A separate equimolar solution of hexamethylenetetramine (HMT) was also prepared in aqueous ethanol (30\%). These solutions were stirred for $30 \mathrm{~min}$ at $60{ }^{\circ} \mathrm{C}$. The growth solution was obtained by slow titration of HMT solution against zinc nitrate solution [34]. The $\mathrm{ZnO}$ substrate was kept inverted in this growth solution for $3 \mathrm{~h}$ at $80{ }^{\circ} \mathrm{C}$ undisturbed. The substrate was removed from the growth solution and dried at room temperature. Then, this substrate was washed with DI water and dried in a vacuum desiccator.

\section{Hybrid nanostructure (ZnO-TF/bR and $\mathrm{ZnO}-\mathrm{NR} / \mathrm{bR}$ ) synthesis}

Amphipol (APol) A8-35, an amphiphilic polymer, was used to stabilise the protein. The $b R$ protein suspension was prepared in aqueous A8-35 (10\%) solution in the ratio of $5: 1(\mathrm{w} / \mathrm{w})$. The bR protein suspension was stored under dark conditions at $4{ }^{\circ} \mathrm{C}$ [37]. Finally, hybrid nanostructures ( $\mathrm{ZnO}-\mathrm{TF} / \mathrm{bR}$ and $\mathrm{ZnO}-\mathrm{NR} /$ bR) were fabricated by manually drop casting $50 \mu \mathrm{L}$ of the bR protein suspension (using a micropipette) on the $\mathrm{ZnO}-\mathrm{TF}$ and ZnO-NR substrates $\left(625 \mathrm{~mm}^{2}\right.$ area) [14]. The deposited film was dried in vacuum at room temperature by using a standard $3 \mathrm{~L}$ desiccator connected to a Millipore vacuum pump (4 bar).

\section{Structural characterisation}

$\mathrm{X}$-ray diffraction patterns for the $\mathrm{ZnO}-\mathrm{TF}, \mathrm{ZnO}-\mathrm{NR}$ and respective hybrid structures were recorded using an X-ray diffractometer (Rikgo) with $\mathrm{Cu} \mathrm{K \alpha}$ radiation of wavelength $\lambda=$ $0.1541 \mathrm{~nm}$ in the scan range $2 \theta=20-80^{\circ}$. The surface morphology of these samples was investigated using scanning electron microscope (SEM, Hitachi) with an accelerating voltage of $5-15 \mathrm{kV}$. The film thickness was measured using a surface profilometer in contact mode (Taly-surf PGI 120).

\section{Raman and optical spectral analysis}

The optical absorption spectra of all the nanostructures were recorded using a UV-vis spectrophotometer (Hitachi, $3900 \mathrm{H}$ ). The photoluminescence (PL) spectrum was measured using a Varian spectrofluorometer. The Raman spectra were taken using a $514 \mathrm{~nm}$ wavelength laser source with a Renishaw Invia spectrophotometer. A Perkin Elmer spectrophotometer was used for the FTIR analysis of the samples. The FTIR analysis was carried in ATR mode and the transmission spectra were analysed.

\section{Gas sensing setup}

The gas sensing measurements were carried out in a customized chamber (Taguchi Gas sensing kit). The chamber was sealed to minimize the effect of atmosphere on the substrate. The $\mathrm{ZnO}$ TF and ZnO-NR nanostructures, with and without bR (nonhybrid surface), were placed on a temperature-controlled heating plate inside the microreactor chamber. The chamber was controlled by a PID temperature controller (Schnieder Electric, Japan). The resistance across the substrate was measured using spring-loaded copper electrodes (contact points lightly covered with silver paste and spaced $10 \mathrm{~mm}$ apart) connected to an Agilent Precision source/Measure Unit Model B2901. The baseline resistance (i.e., without gas) of $\mathrm{ZnO}-\mathrm{TF}, \mathrm{ZnO}-\mathrm{NR}, \mathrm{ZnO}-$ $\mathrm{TF} / \mathrm{bR}$ and $\mathrm{ZnO}-\mathrm{NR} / \mathrm{bR}$ structures was observed to be 
$2.22 \times 10^{2} \Omega, 1.45 \times 10^{2} \Omega, 2.31 \times 10^{2} \Omega$ and $2.45 \times 10^{2} \Omega$, respectively. The sensing setup is shown in Figure 8. Known volumes of ethanol were injected onto a petri dish mounted on a preheated $\left(80^{\circ} \mathrm{C}\right)$ heating plate placed inside the chamber. The vapour concentration was calculated using the equation given by Yinhua et al. [74]:

$$
C(\mathrm{ppm})=K \frac{V_{\mathrm{L}} D_{\mathrm{L}} T}{M_{\mathrm{L}} V_{\mathrm{A}}} .
$$

where, $K$ is a constant having a value of $8.2 \times 10^{4}, T$ is the operating temperature in Kelvin, $V_{\mathrm{A}}$ is the volume $(\mathrm{mL})$ of the diluting gas (which is equal to the volume of the test chamber), and $V_{\mathrm{L}}, D_{\mathrm{L}}$ and $M_{\mathrm{L}}$ refer to the volume $(\mathrm{mL})$, density $\left(\mathrm{g} \mathrm{mL}^{-1}\right)$ and molecular weight $\left(\mathrm{g} \mathrm{mol}^{-1}\right)$ of the liquid organic analyte (ethanol), respectively.

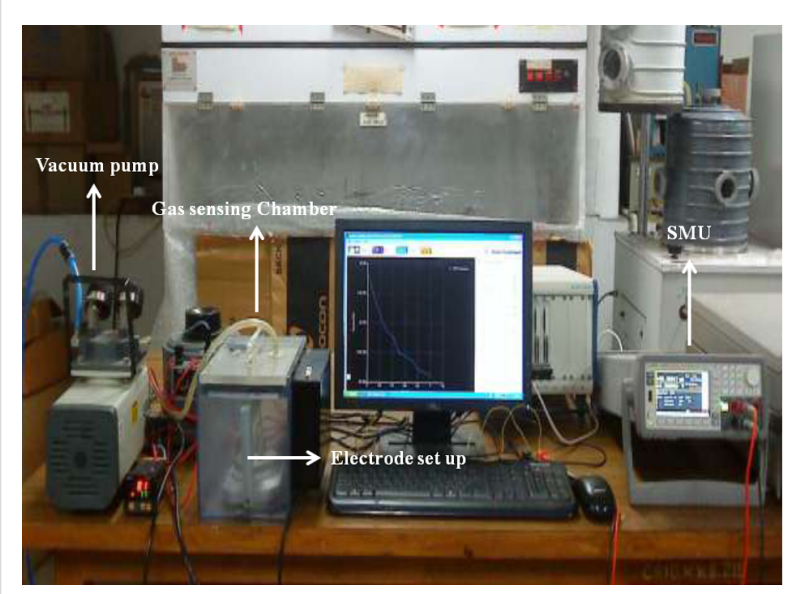

Figure 8: Gas sensing setup.

\section{Acknowledgements}

The authors extend their sincere thanks to Professor M.C. Bhatnagar, Department of Physics, IIT-Delhi, to Mrs. Monika Singla, Technical Officer, to Mr. Sankho T. Sarkar (SRF) CSIR-CSIO, and to Mr. Brajesh Nandan, Research Scholar, IIT-Delhi, for their input and assistance.

\section{References}

1. Saptarshi, S. R.; Duschl, A.; Lopata, A. L. J. Nanobiotechnol. 2013, 11, 26. doi:10.1186/1477-3155-11-26

2. Chatterjee, T.; Chakraborti, S.; Joshi, P.; Singh, S. P.; Gupta, V.; Chakrabarti, P. FEBS J. 2010, 277, 4184-4194. doi:10.1111/j.1742-4658.2010.07807.x

3. Bhunia, A. K.; Samanta, P. K.; Saha, S.; Kamilya, T. Appl. Phys. Lett. 2013, 103, 143701. doi:10.1063/1.4824021

4. Nel, A. E.; Mädler, L.; Velegol, D.; Xia, T.; Hoek, E. M. V.; Somasundaran, P.; Klaessig, F.; Castranova, V.; Thompson, M. Nat. Mater. 2009, 8, 543-557. doi:10.1038/nmat2442
5. Stuart, J. A.; Marcy, D. L.; Birge, R. R. Bacteriorhodopsin-based photochromic sensor for detection of chemical and environmental toxins. U.S. Patent 8163539 B2 April 24, 2012.

6. Ackley, D. E.; Shieh, C.-L. Thin film transistor bio/chemical sensor. U.S. Patent 5719033 A Feb 17, 1998.

7. Birge, R. R.; Gillespie, N. B.; Izaguirre, E. W.; Kusnetzow, A.; Lawrence, A. F.; Singh, D.; Song, Q. W.; Schmidt, E.; Stuart, J. A.; Seetharaman, S.; Wise, K. J. J. Phys. Chem. B 1999, 103, 10746-10766. doi:10.1021/jp991883n

8. He, J.-A.; Samuelson, L.; Li, L.; Kumar, J.; Tripathy, S. K. Adv. Mater. 1999, 11, 435-446. doi:10.1002/(SICI)1521-4095(199904)11:6<435::AID-ADMA435>3.0.C O;2-U

9. Bulpett, J. M.; Collins, A. M.; Kaus, N. H. M.; Cresswell, P. T.; Bikondoa, O.; Walsh, D.; Mann, S.; Davis, S. A.; Briscoe, W. H. J. Mater. Chem. 2012, 22, 15635-15643. doi:10.1039/c2jm32467a

10. Crittenden, S.; Howell, S.; Reifenberger, R.; Hillebrecht, J.; Birge, R. R. Nanotechnology 2003, 14, 562. doi:10.1088/0957-4484/14/5/315

11. Korposh, S. O.; Sichka, M. Y.; Trikur, I. I.; Sharkan, Y. P.; Yang, D. H.; Lee, S. W.; Ramsden, J. J. Films based on bacteriorhodopsin in sol-gel matrices. In Proc. SPIE 5956, Warsaw, Poland, Aug 28, 2005; Pustelny, T.; Lambeck, P. V.; Gorecki, C., Eds.; p 595616. doi:10.1117/12.622631

12. Horn, C.; Steinem, C. Biophys. J. 2005, 89, 1046-1054. doi:10.1529/biophysj.105.059550

13. Jin, Y.; Honig, T.; Ron, I.; Friedman, N.; Sheves, M.; Cahen, D. Chem. Soc. Rev. 2008, 37, 2422-2432. doi:10.1039/b806298f

14. Wang, W. W.; Knopf, G. K.; Bassi, A. S. Biosens. Bioelectron. 2006, 21, 1309-1319. doi:10.1016/j.bios.2005.06.003

15. Li, L. S.; Xu, T.; Zhang, Y. J.; Jin, J.; Li, T. J.; Zou, B.; Wang, J.-P. J. Vac. Sci. Technol., A 2001, 19, 1037-1041. doi:10.1116/1.1369785

16. Ingrosso, C.; Bianco, G. V.; Lopalco, P.; Tamborra, M.; Curri, M. L.; Corcelli, A.; Bruno, G.; Agostiano, A.; Siciliano, P.; Striccoli, M. Nanoscale 2012, 4, 6434-6441. doi:10.1039/c2nr31999c

17. Alfinito, E.; Reggiani, L. Europhys. Lett. 2009, 85, 68002. doi:10.1209/0295-5075/85/68002

18. Li, R.; Li, C. M.; Bao, H.; Bao, Q.; Lee, V. S. Appl. Phys. Lett. 2007, 91, 223901. doi:10.1063/1.2801521

19. Kim, Y. J.; Neuzil, P.; Nam, C.-H.; Engelhard, M. Sensors 2013, 13, 455-462. doi:10.3390/s130100455

20. Thavasi, V.; Lazarova, T.; Filipek, S.; Kolinski, M.; Querol, E.; Kumar, A.; Ramakrishna, S.; Padrós, E.; Renugopalakrishnan, V. J. Nanosci. Nanotechnol. 2009, 9, 1679-1687. doi:10.1166/jnn.2009.SI07

21. Sharkany, J. P.; Korposh, S. O.; Batori-Tarci, Z. I.; Trikur, I. I.; Ramsden, J. J. Sens. Actuators, B 2005, 107, 77-81. doi:10.1016/j.snb.2004.11.101

22. Korposh, S. O.; Sharkan, Y. P.; Ramsden, J. J. Sens. Actuators, B 2008, 129, 473-480. doi:10.1016/j.snb.2007.08.024

23. Arya, S. K.; Saha, S.; Ramirez-Vick, J. E.; Gupta, V.; Bhansali, S.; Singh, S. P. Anal. Chim. Acta 2012, 737, 1-21. doi:10.1016/j.aca.2012.05.048

24. Özgur, Ü.; Alivov, Y. I.; Liu, C.; Teke, A.; Reshchikov, M. A.; Doğan, S.; Avrutin, V.; Cho, S.-J.; Morkoç, H. J. Appl. Phys. 2005, 98, 41301. doi:10.1063/1.1992666

25. Ozgur, U.; Hofstetter, D.; Morkoç, H. ZnO Devices and Applications: A Review of Current Status and Future Prospects. In Proceedings of the IEEE, 2010; pp 1255-1268. doi:10.1109/JPROC.2010.2044550

26. Zhang, Y.; Ram, M. K.; Stefanakos, E. K.; Goswami, D. Y. J. Nanomater. 2012, 2012, No. 624520. doi:10.1155/2012/624520 
27. Wang, Z. L. J. Phys.: Condens. Matter 2004, 16, R829. doi:10.1088/0953-8984/16/25/R01

28. Seiyama, T.; Kato, A.; Fujiishi, K.; Nagatani, M. Anal. Chem. 1962, 34, 1502-1503. doi:10.1021/ac60191a001

29. Xu, H.; Liu, X.; Cui, D.; Li, M.; Jiang, M. Sens. Actuators, B 2006, 114, 301-307. doi:10.1016/j.snb.2005.05.020

30. Shafiei, M.; Yu, J.; Arsat, R.; Kalantar-Zadeh, K.; Comini, E.; Ferroni, M.; Sberveglieri, G.; Wlodarski, W. Sens. Actuators, B 2010, 146, 507-512. doi:10.1016/j.snb.2009.12.028

31. Sun, Z.-P.; Liu, L.; Zhang, L.; Jia, D.-Z. Nanotechnology 2006, 17, 2266. doi:10.1088/0957-4484/17/9/032

32. Ding, B.; Wang, M.; Yu, J.; Sun, G. Sensors 2009, 9, 1609-1624. doi:10.3390/s90301609

33. Calestani, D.; Zha, M.; Mosca, R.; Zappettini, A.; Carotta, M. C.; Di Natale, V.; Zanotti, L. Sens. Actuators, B 2010, 144, 472-478. doi:10.1016/j.snb.2009.11.009

34. Baruah, S.; Dutta, J. Sci. Technol. Adv. Mater. 2009, 10, 13001. doi:10.1088/1468-6996/10/1/013001

35. Vergés, M. A.; Mifsud, A.; Serna, C. J. J. Chem. Soc., Faraday Trans. 1990, 86, 959-963. doi:10.1039/ft9908600959

36. Ridhuan, N. S.; Razak, K. A.; Lockman, Z.; Aziz, A. A. PLoS One 2012, 7, e50405. doi:10.1371/journal.pone.0050405

37. Gohon, Y.; Dahmane, T.; Ruigrok, R. W. H.; Schuck, P.; Charvolin, D.; Rappaport, F.; Timmins, P.; Engelman, D. M.; Tribet, C.; Popot, J.-L.; Ebel, C. Biophys. J. 2008, 94, 3523-3537. doi:10.1529/biophysj.107.121848

38. Lupan, O.; Chow, L.; Rudzevich, Y.; Lin, Y.; Park, S.; Schulte, A.; Monaico, E.; Ghimpu, L.; Sontea, V.; Trofim, V.; Railean, S.; Cretu, V.; Pocaznoi, I. Rapid hydrothermal synthesis of zinc oxide nanorods on single crystal sapphire substrate. In Semiconductor Conference (CAS), 2011 International, Sinaia, Romania, Oct 17-19, 2011; IEEE, 2011; pp 241-244. doi:10.1109/smicnd.2011.6095781

39. Shouli, B.; Liangyuan, C.; Dianqing, L.; Wensheng, Y.; Pengcheng, Y.; Zhiyong, L.; Aifan, C.; Liu, C. C. Sens. Actuators, B 2010, 146, 129-137. doi:10.1016/j.snb.2010.02.011

40. Cullity, B. D.; Stock, S. R. Elements of X-ray diffraction, 3rd ed.; Prentice Hall: Upper Saddle River, NJ, 2001.

41. Ting, C.-C. Structure, Morphology, and Optical Properties of the Compact, Vertically Aligned ZnO Nanorod Thin Films by the Solution-Growth Technique. In Nanorods; Yalçın, O., Ed.; InTech: Shanghai, China, 2012; pp 33-50. doi:10.5772/35533

42. Chakraborty, R.; Dhara, S.; Giri, P. K. Int. J. Nanosci. 2011, 10, 65-68. doi:10.1142/S0219581X1100751X

43. Samuel, M. S.; Bose, L.; George, K. C. SB Academic Review 2009, 16, 57-65.

44. Marti, T. J. Biol. Chem. 1998, 273, 9312-9322. doi:10.1074/jbc.273.15.9312

45. Rehorek, M.; Heyn, M. P. Biochemistry 1979, 18, 4977-4983. doi:10.1021/bi00589a027

46. Becher, B.; Tokunaga, F.; Ebrey, T. G. Biochemistry 1978, 17, 2293-2300. doi:10.1021/bi00605a006

47. Muccio, D. D.; Cassim, J. Y. Biophys. J. 1979, 26, 427-440. doi:10.1016/S0006-3495(79)85263-7

48. Chen, Y.; Bagnall, D. M.; Koh, H.-j.; Park, K.-t.; Hiraga, K.; Zhu, Z.; Yao, T. J. Appl. Phys. 1998, 84, 3912-3918. doi:10.1063/1.368595

49. Cho, S.; Ma, J.; Kim, Y.; Sun, Y.; Wong, G. K. L.; Ketterson, J. B. Appl. Phys. Lett. 1999, 75, 2761-2763. doi:10.1063/1.125141

50. Lee, G. J.; Lee, Y. P.; Lim, H.-H.; Cha, M.; Kim, S. S.; Cheong, H.; Min, S.-K.; Han, S.-H. J. Korean Phys. Soc. 2010, 57, 1624-1629. doi:10.3938/jkps.57.1624
51. Hsieh, P.-T.; Chen, Y.-C.; Wang, C.-M.; Tsai, Y.-Z.; Hu, C.-C. Appl. Phys. A 2006, 84, 345-349. doi:10.1007/s00339-006-3620-2

52. Djurišić, A. B.; Leung, Y. H.; Tam, K. H.; Hsu, Y. F.; Ding, L.; Ge, W. K.; Zhong, Y. C.; Wong, K. S.; Chan, W. K.; Tam, H. L. Nanotechnology 2007, 18, 95702. doi:10.1088/0957-4484/18/9/095702

53. Liu, F.; Cao, P. J.; Zhang, H. R.; Shen, C. M.; Wang, Z.; Li, J. Q.; Gao, H. J. J. Cryst. Growth 2005, 274, 126-131. doi:10.1016/j.jcrysgro.2004.09.080

54. Bagnall, D. M.; Chen, Y. F.; Zhu, Z.; Yao, T.; Shen, M. Y.; Goto, T. Appl. Phys. Lett. 1998, 73, 1038-1040. doi:10.1063/1.122077

55. Porto, S. P. S.; Giordmaine, J. A.; Damen, T. C. Phys. Rev. 1966, 147, 608. doi:10.1103/PhysRev.147.608

56. Kaschner, A.; Haboeck, U.; Strassburg, M.; Strassburg, M.; Kaczmarczyk, G.; Hoffmann, A.; Thomsen, C.; Zeuner, A.; Alves, H. R.; Hofmann, D. M.; Meyer, B. K. Appl. Phys. Lett. 2002, 80, 1909-1911. doi:10.1063/1.1461903

57. Arguello, C. A.; Rousseau, D. L.; Porto, S. P. S. Phys. Rev. 1969, 181, 1351. doi:10.1103/PhysRev.181.1351

58. Mahmood, K.; Park, S. B.; Sung, H. J. J. Mater. Chem. C 2013, 1, 3138-3149. doi:10.1039/c3tc00082f

59. Kerr, L. L.; Li, X.; Canepa, M.; Sommer, A. J. Thin Solid Films 2007, 515, 5282-5286. doi:10.1016/j.tsf.2006.12.186

60. Šćepanović, M.; Grujić-Brojčin, M.; Vojisavljević, K.; Bernik, S.; Srećković, T. J. Raman Spectrosc. 2010, 41, 914-921. doi:10.1002/jrs.2546

61. Althaus, T.; Eisfeld, W.; Lohrmann, R.; Stockburger, M. Isr. J. Chem. 1995, 35, 227-251. doi:10.1002/ijch.199500029

62. Saikia, J.; Saha, B.; Das, G. J. Nanopart. Res. 2012, 14, 1-13. doi:10.1007/s11051-012-1226-5

63. Chirgadze, Y. N.; Fedorov, O. V.; Trushina, N. P. Biopolymers 1975, 14, 679-694. doi:10.1002/bip.1975.360140402

64. Szaraz, S.; Oesterhelt, D.; Ormos, P. Biophys. J. 1994, 67, 1706-1712. doi:10.1016/S0006-3495(94)80644-7

65. Asher, I. M.; Levin, I. W. Biochim. Biophys. Acta, Biomembr. 1977, 468, 63-72. doi:10.1016/0005-2736(77)90151-1

66. Lee, D. C.; Herzyk, E.; Chapman, D. Biochemistry 1987, 26, 5775-5783. doi:10.1021/bi00392a029

67. Gerwert, K.; Siebert, F. EMBO J. 1986, 5, 805-811.

68. He, J.-A.; Samuelson, L.; Li, L.; Kumar, J.; Tripathy, S. K. Langmuir 1998, 14, 1674-1679. doi:10.1021/la971336y

69. He, J.-A.; Valluzzi, R.; Yang, K.; Dolukhanyan, T.; Sung, C.; Kumar, J.; Tripathy, S. K.; Samuelson, L.; Balogh, L.; Tomalia, D. A. Chem. Mater. 1999, 11, 3268-3274. doi:10.1021/cm990311c

70. Ng, K. C.; Chu, L.-K. J. Phys. Chem. B 2013, 117, 6241-6249. doi:10.1021/jp401254j

71. Rothschild, K. J.; Clark, N. A. Biophys. J. 1979, 25, 473-487. doi:10.1016/S0006-3495(79)85317-5

72. Asai, M.; Tsuboi, M.; Shimanouchi, T.; Mizushima, S. J. Phys. Chem. 1955, 59, 322-325. doi:10.1021/j150526a011

73. Moltke, S.; Heyn, M. P. Biophys. J. 1995, 69, 2066-2073. doi:10.1016/S0006-3495(95)80077-9

74. Li, Y.; Gong, J.; He, G.; Deng, Y. Mater. Chem. Phys. 2012, 134, 1172-1178. doi:10.1016/j.matchemphys.2012.04.014

75. Wan, Q.; Li, Q. H.; Chen, Y. J.; Wang, T. H.; He, X. L.; Li, J. P.; Lin, C. L. Appl. Phys. Lett. 2004, 84, 3654-3656. doi:10.1063/1.1738932

76. Simion, C. E.; Tomescu-Stanoiu, A. Differences in the gas sensing properties readout with $\mathrm{n}$ and $\mathrm{p}$-type MOX materials. In Semiconductor Conference (CAS), 210 International, Sinaia, Romania, Oct 11-13, 2010; IEEE, 2010; pp 201-204. doi:10.1109/smicnd.2010.5649077 
77. Zhang, D.; Wang, K.; Tong, J.; Xia, B.

Indones. J. Electr. Eng. Comput. Sci. 2013, 11, 6120-6126.

78. Ouyang, M.; Li, W. J. Reusable CNTs-based chemical sensors. In Nano/Molecular Medicine and Engineering (NANOMED), International Conference on IEEE, Tainan, Taiwan, Oct 18-21, 2009; IEEE, 2009; pp 188-192. doi:10.1109/nanomed.2009.5559088

79. Coppedè, N.; Villani, M.; Mosca, R.; lannotta, S.; Zappettini, A.;

Calestani, D. Sensors 2013, 13, 3445-3453. doi:10.3390/s130303445

80. Berthoumieu, O.; Patil, A. V.; Xi, W.; Aslimovska, L.; Davis, J. J.; Watts, A. Nano Lett. 2012, 12, 899-903. doi:10.1021/nl203965w

81. Luković Golić, D.; Branković, G.; Počuča Nešić, M.; Vojisavljević, K.; Rečnik, A.; Daneu, N.; Bernik, S.; Sćepanović, M.; Poleti, D.; Branković, Z. Nanotechnology 2011, 22, 395603. doi:10.1088/0957-4484/22/39/395603

82. Guo, M.; Diao, P.; Wang, X.; Cai, S. J. Solid State Chem. 2005, 178, 3210-3215. doi:10.1016/j.jssc.2005.07.013

83. Wang, J. X.; Sun, X. W.; Yang, Y.; Huang, H.; Lee, Y. C.; Tan, O. K.; Vayssieres, L. Nanotechnology 2006, 17, 4995. doi:10.1088/0957-4484/17/19/037

\section{License and Terms}

This is an Open Access article under the terms of the Creative Commons Attribution License

(http://creativecommons.org/licenses/by/2.0), which permits unrestricted use, distribution, and reproduction in any medium, provided the original work is properly cited.

The license is subject to the Beilstein Journal of

Nanotechnology terms and conditions:

(http://www.beilstein-journals.org/bjnano)

The definitive version of this article is the electronic one which can be found at:

doi:10.3762/bjnano.7.44 